\title{
PROTECTION FROM GENDER-BASED VIOLENCE BEFORE THE EUROPEAN COURT OF HUMAN RIGHTS
}

\author{
Jelena Ristik \\ School of Law, University American College - Skopje, North Macedonia \\ ORCID iD: https://orcid.org/0000-0001-8559-3404 \\ jelena.ristik@uacs.edu.mk \\ jristik@hotmail.com
}

\begin{abstract}
Despite the lack of specific provisions in the European Convention on Human Rights regarding genderbased violence, the European Court of Human Rights has developed a substantial body of case-law in this area. It has been done through the interpretation and application of a number of provisions in the European Convention on Human Rights that are relevant to gender-based violence. This paper provides a review of the approach of the European Court of Human Rights in cases concerning gender-based violence. Namely, it is evident that a remarkable spate of cases dealing with gender-based violence is considered by the European Court of Human Rights, which provides very solid protection in this field. However, it seems that certain aspects of the case-law on gender-based violence are somewhat inconsistent. In this sense, having in mind that the judgments of the European Court of Human Rights are the main guidelines for the States in fulfilling their obligations arising from the Convention, it is very important for the Court to fully clarify its approach in this regard.
\end{abstract}

Keywords: Gender-Based Violence; Violence against Women; European Convention on Human Rights; European Court of Human Rights; Istanbul Convention

\section{INTRODUCTION}

The European Convention on Human Rights ('ECHR' or 'the Convention') is Europe's core human rights treaty, which guarantees the rights and freedoms it includes to everyone within the jurisdiction of the Member States of the Council of Europe. Based on the ECHR, the European Court of Human Rights ('ECtHR or 'the Court') has issued a significant number of judgments and decisions as regards cases concerning gender-based violence ('GBV'), 
despite the fact that the Convention does not include any specific provisions in that regard. However, there are a number of provisions in the Convention that have been identified as relevant to GBV, and were used by the ECtHR to develop an extensive case-law in this sphere. Those provisions are Article 2 (right to life), Article 3 (prohibition of torture), Article 4 (prohibition of slavery and forced labor), Article 6 (right to a fair trial), Article 8 (right to respect for private and family law), Article 13 (right to an effective remedy), Article 14 (prohibition of discrimination) and Protocol 12 to the Convention (general prohibition of discrimination). Namely, based on the interpretation and application of these provisions, the ECtHR has developed standards regarding GBV and provided protection before the Court in this field. This paper has placed its focus on providing a review of the approach of the ECtHR in cases dealing with GBV. In that sense, it will first define the concept of GBV and the relevant international legal framework, especially having in mind that no consensus has been achieved yet as regards the meaning of the term 'GBV', which is often interchangeably used with the term violence against women ('VAW'). The second part of the paper will encompass analysis of the evolution and treatment of different forms of GBV in the case-law of the ECtHR.

A special focus will be placed on cases of domestic violence, and rape and sexual abuse, since most cases concerning GBV that are brought before the Court are related to these forms of GBV. The next part deals with the Istanbul Convention, as the most comprehensive and far-reaching international treaty to address VAW, exploring its use by the Court as a means for interpretation of the ECHR. Lastly, the results of the analysis as regards the approach of the ECtHR in cases dealing with GBV will be summarized.

\section{GENDER-BASED VIOLENCE: DEFINITION AND INTERNATIONAL LEGAL FRAMEWORK}

The term gender-based violence and the term violence against women are often used interchangeably, including in some international conventions (Duban and Radacic 2017, 44), as it has been widely acknowledged that most gender-based violence is inflicted on women and girls, by men (World Health Organization 2013; World Health Organization 2017). However, it seems that there are not synonymous, as GBV is increasingly used as a more expansive term compared to VAW (World Health Organization 2013; World Health Organization 2017). The CEDAW General recommendation 19 (UN Committee on the Elimination of Discrimination against Women (CEDAW) 1992) gave the first international law definition of GBV in 1992, as "a form of discrimination that seriously inhibits women's ability to enjoy rights and freedoms on a basis of equality with men". It further stipulates that "the definition of discrimination includes gender-based violence, that is, violence that is directed against a woman because she is a woman or that affects women disproportionately" (CEDAW 1992).

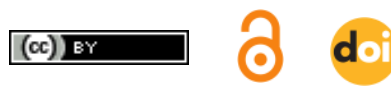


The widespread use of the term 'GBV' followed after its inclusion in the UN Declaration on the Elimination of All Forms of Violence against Women in 1993 (UN General Assembly 1993). It defined the term ' $V A W$ ' as "any act of gender-based violence that results in, or is likely to result in, physical, sexual or psychological harm or suffering to women, including threats of such acts, coercion or arbitrary deprivation of liberty, whether occurring in public or in private life" (UN General Assembly 1993, Article 1). Accordingly, it seems that the term 'GBV' was originally adopted in order to articulate the problem regarding VAW. However, although VAW is defined by reference to GBV, there is no definition of the term 'gender'.

The first regional binding instrument on violence against women, the Inter-American Convention on the Prevention, Punishment and Eradication of Violence against Women from 1994 (Organization of American States (OAS) 1994), known as Convention of Belém do Pará, defines VAW as "any act or conduct, based on gender, which causes death or physical, sexual or psychological harm or suffering to women, whether in the public or the private sphere". The term 'GBV' is not used in this Convention.

The second regional binding instrument on violence against women, the Protocol to the African Charter on Human and Peoples' Rights on the Rights of Women in Africa from 2003 (African Union 2003), known as Maputo Protocol, uses the term 'gender-based violence against women'. Namely, the State Parties to the Protocol agree "to take concrete steps to give greater attention to the human rights of women in order to eliminate all forms of discrimination and of gender-based violence against women". The term 'VAW' is defined as "all acts perpetrated against women which cause or could cause them physical, sexual, psychological, and economic harm, including the threat to take such acts; or to undertake the imposition of arbitrary restrictions on or deprivation of fundamental freedoms in private or public life in peace time and during situations of armed conflicts or of war" (African Union 2003, Article 1).

The Council of Europe Convention on Preventing and Combating Violence against Women and Domestic Violence from 2011 (Council of Europe 2011), known as Istanbul Convention, which is the third regional binding instrument, also uses the term 'gender-based violence against women'. Unlike the Maputo Protocol, the Istanbul Convention provides a definition of the term 'gender-based violence against women', as "violence that is directed against a woman because she is a woman or that affects women disproportionately" (Council of Europe 2011, Article 3). Moreover, the Istanbul Convention defines as well the term 'gender', as "the socially constructed roles, behaviors, activities and attributes that a given that a given society considers appropriate for women and men" (Council of Europe 2011, Article 3). VAW is defined as "a violation of human rights and a form of discrimination against women and shall mean all acts of gender-based violence that result in, or are likely to result in, physical, sexual, psychological or economic harm or suffering to women, including threats of such acts, coercion or arbitrary deprivation of liberty, whether occurring in public or in private life" (Council of Europe 2011, Article 3). 
The use of the term 'gender-based violence against women', as well as the definition of the term 'gender', implies that GBV does not have to be directed only at women. Moreover, in this sense, the Preamble of the Istanbul Convention states that "women and girls are exposed to a higher risk of gender-based violence than men" (Council of Europe 2011). Similarly, the Explanatory Report to the Istanbul Convention states that "the fact that women experience gender-based violence, including domestic violence, to a significantly larger extent than men can be considered an objective and reasonable justification to employ resources and take special measures for the benefit of women victims only" (Council of Europe 2011a, 10). It also states that "violence against women, including domestic violence, is one of the most serious forms of gender-based violations of human rights in Europe" (Council of Europe 2011a, 1). Thus, it seems that there is a tendency to use the term ' $G B V$ ' in a broader sense, in terms of violence that is being directed at a person on the basis of gender, and that also encompass VAW as one of its forms. It implies that men can also be targets of GBV, and, consequently, that the terms 'GBV' and 'VAW' are not synonymous. Moreover, it is explicitly stated in the Preamble of the Istanbul Convention that "domestic violence affects women disproportionately, and that men may also be victims of domestic violence" (Council of Europe 2011).

However, it should be also noted that the Explanatory Report to the Istanbul Convention foresees that "the use of the expression 'gender-based violence against women' (...) is understood as equivalent to the expression 'gender-based violence' used in the CEDAW Committee General Recommendation No. 19 on violence against women (1992), the United Nations General Assembly Declaration on the Elimination of Violence against Women (1993) (...)" as well as that "this expression is to be understood as aimed at protecting women from violence resulting from gender stereotypes, and specifically encompasses women"(Council of Europe 2011a, 8).

On the other hand, various UN entities use the term 'GBV' in its broad sense. According to the UN High Commissioner for Human Rights, GBV is "any harmful act directed against individuals or groups of individuals on the basis of their gender" (UN Human Rights Office of the High Commissioner 2014). It recognizes that "victims of such violence continue to be disproportionally women and girls", but that "men and boys are also targets of genderbased and sexual violence" (UN Human Rights Office of the High Commissioner 2014). Namely, GBV is used as "an umbrella term used to distinguish common violence from violence that is directed against individuals or groups of individuals on the basis of their sex, gender identity or socially ascribed gender roles" (UN Human Rights Office of the High Commissioner 2011, 29). However, it is noteworthy that this definition is supplemented by the assertion that "while women, men, boys and girls can all be victims of gender-based violence, the primary victims have been women and girls" (UN Human Rights Office of the High Commissioner 2011, 29). In addition, it is also recognized that "violence against lesbian, gay, bisexual, transgender and intersex people also often based on gender" (UN Human Rights Office of the High Commissioner 2011, 29). 
The UN High Commissioner for Refugees also employs an inclusive conception of the term 'GBV', which is "used to distinguish common violence from violence that targets individuals or groups of individuals on the basis of their gender" (UN High Commissioner for Refugees 2003, 10). Namely, according to the UN High Commissioner for Refugees, GBV "also hinders the development of men and boys" (UN High Commissioner for Refugees 2003, 10). However, it is recognized as well that "gender-based violence has a devastating impact on the lives of women and girls who are the majority of victims/survivors" (UN High Commissioner for Refugees 2003, 10).

\section{APPROACH OF THE EUROPEAN COURT OF HUMAN RIGHTS TO CASES CONCERNING GENDER-BASED VIOLENCE}

The European Court of Human Rights has issued a number of important judgments that formulate standards in the sphere of protection from GBV, which cover almost all types of GBV.As it has been widely acknowledged that most gender-based violence is inflicted on women and girls, for the purpose of the analysis of the jurisprudence of the ECtHR in this sense, the term 'VAW' will be used as a synonym of GBV. In fact, the thematic factsheet issued by the ECtHR as regards its case-law on GBV use the term 'VAW' (European Court of Human Rights 2020). Namely, it refers to various forms of VAW addressed in the case-law of the Court.

The Court has examined a number of cases concerning violence against women, committed both by the state and private individuals. It has addressed almost all forms of VAW (European Court of Human Rights 2020), such as:

1. Domestic violence (Airey v. Ireland (1979); Osman v. the United Kingdom (1998); Kontrovà v. Slovakia (2007); Bevacqua and S. v. Bulgaria (2008); BrankoTomašić and Others v. Croatia (2009); Opuz v. Turkey (2009); E.S. and Others v. Slovakia (2009); D.M.D. v. Romania; N. v. Sweden (2010); A. v. Croatia (2010); Hajduovà v. Slovakia (2010); E.M. v. Romania (2012); Y.C. v. the United Kingdom (2012); Kalucza v. Hungary (2012); Kowal v. Poland (2012) (decision on admissibility); Irene Wilson v. the United Kingdom (2012) (decision on admissibility); Valiuliene v. Lithuania (2013); Eremia and Others v. the Republic of Moldova (2013); D.P. v. Lithuania (2013) (strike-out decision); Rumor v. Italy (2014); Durmaz v. Turkey (2014); Wasiewska v. Poland (2014) (decision on admissibility); Civek v. Turkey (2016); HalimeKilic v. Turkey (2016); M.G. v. Turkey (2016); Bălsan v. Romania (2017); Talpis v. Italy (2017); O.C.I. and Others v. Romania (2019) (Committee judgment); Kurt v. Austria (2019); Volodina v. Russia (2019))

2. Rape and Sexual Abuse ( $X$ and $Y$ v. the Netherlands (1985); C.R. v. the United Kingdom (1995); S.W. v. the United Kingdom (1995); Aydin v. Turkey (1997); M.C. v. Bulgaria (2003); Maslova and Nalbandov v. Russia (2008); P.M. v. Bulgaria (2012); I.G. v. Republic of Moldova (2012); M. and Others v. Italy and Bulgaria (2012); P. and S. V. Poland (2012); O'Keeffe v. Ireland (2014)(Grand Chamber); W. v. Slovenia (2014); M.A. 
v. Slovenia and N.D. v. Slovenia (2015); S.Z. v. Bulgaria (2015); I.P. v. the Republic of Moldova (2015); Y. v. Slovenia (2015); M.G.C. v. Romania (2016); I.C. v. Romania (2016); B.V. v. Belgium (2017); E.B. v. Romania (2019) (Committee judgment))

3. Risk of ill-treatment in case of expulsion (for fear of):

a. Female genital mutilation (Collins and Akaziebie v. Sweden (2007) (decision on admissibility; Izevbekhai v. Ireland (2011) (decision on admissibility); Omeredo v. Austria (2011) (decision on admissibility); Sow v. Belgium (2016); Bangura v. Belgium (2016) (strike-out decision))

b. Honour crime and III-treatment by the family (A.A. and Others v. Sweden (2012); R.D. v. France (2016))

c. Risk of trafficking or re-traffcking (L.R. v. the United Kingdom (2011) (strike-out decision); V.F. V. France (2011) (decision on admissibility); F.A. V. the United Kingdom (2013) (decision on admissibility); O.G.O. v. the United Kingdom (2014) (strike-out decision))

d. Social exclusion (N. v. Sweden (2010); W.H. v. Sweden (2015) (Grand Chamber); R.H. v. Sweden (2015))

4. Police violence (Aydin v. Turkey (1997); Y.F. v. Turkey (2003); Maslova and Nalbandov v. Russia (2008); YazgülYilmaz v. Turkey (2011); B.S. v. Spain (2012); Izci v. Turkey (2013); AfetSüreyyaEren v. Turkey (2015); DilekAslan v. Turkey (2015); EbruDincer v. Turkey (2019))

5. IIl-treatment in detention (Juhnke v. Turkey (2003)

6. Trafficking in human beings (Rantsev v. Cyprus and Russia (2010); L.E. v. Greece (2016); J. and Others v. Austria (2017))

7. Violence by private individuals (Sandra Janković v. Croatia (2009); Ebcin v. Turkey (2011); Irina Smirnova v. Ukraine (2016))

In a number of key judgments concerning different forms of VAW, the ECtHR has formulated and developed various principles and standards that lay the foundation for securing protection from GBV. Given that most cases concerning GBV that are brought before the Court are related to domestic violence, and rape and sexual abuse, the main focus will be placed on these type of cases.

The cases Airey v. Ireland (9 October 1979, Series A no. 39) and Osman v. the United Kingdom (28 October 1998, Reports of Judgments and Decisions 1998-VIII) do not deal directly with violence against women. However, they are important in this regard as they lay a foundation for the concepts subsequently used by the Court.

The case Airey v. Ireland (9 October 1979, Series A no. 39) involves violence against women since Mrs Aireysought to separate from her husband, who threatened her with physical violence, and occasionally subjected her to physical violence. Due to lack of financial resources and in the absence of legal aid provided by the State, she had been unable to engage a lawyer to represent her before the Court. Among the other, she alleged a violation 
of Article 6 and Article 8. The ECtHR found that the high costs of seeking a separation order before the Irish courts have violated the applicant's right to access to court under Article 6 of the ECHR. The Court also found that the inability to obtain a judicial separation from her husband constituted a violation of the applicant right to respect for her private and family life under Article 8 of the ECHR.

The importance of this judgment is in recognizing that Article 8 , besides its primarily negative undertaking, also imposes a positive obligation inherent in an effective respect for private or family life. Namely, this case is one of the founders of the concept of positive obligations arising under the Convention for the State Parties.

In the case Osman v. the United Kingdom (28 October 1998, Reports of Judgments and Decisions 1998-VIII), the Court further articulated the responsibility of the national authorities for private acts. In this case, the applicant's husband was killed by her son's former teacher, while her son was seriously wounded. Before the accident took place, the teacher had already threatened the applicant and her family. She complained that the national authorities have failed to protect the right to life of her husband from the threat posed by the teacher. However, the ECtHR did not find a violation of Article 2 of the Convention. According to the Court's reasoning, Article 2 implied a positive obligation on the authorities to take preventive measures to protect an individual whose life is at risk from the criminal acts of another individual. Yet, the Court concluded that the facts in the case did not show that the police knew or ought to have known that the lives of the Osman family were at real and immediate risk from the teacher.

Accordingly, the national authorities did not breach Article 2. This case is important because the Court determined criteria to be followed in order to establish that the national authorities have violated their positive obligation to protect the right to life. According to the Court, "it must be established (...) that the authorities knew or ought to have known at the time of the existence of a real and immediate risk to the life of an identified individual or individuals from the criminal acts of a third party and that they failed to take measures within the scope of their powers which, judged reasonably, might have been expected to avoid that risk" (Osman v. the United Kingdom, 28 October 1998, § 115, Reports of Judgments and Decisions 1998-VIII). These criteria are known as the 'Osman test'.

In its further cases, the Court continued to use the 'Osman test' and applied it in domestic violence cases. Namely, in the case Kontrová v. Slovakia (no. 7510/04, 31 May 2007), the Court extended the positive obligations inherent in Article 2 of the Convention to the domestic context. It should be taken into account that the Court did not directly address the abuse suffered by the applicant, but the violation was found as regards the rights of the children. Nevertheless, the significant aspect of this case is that the findings explicitly apply to domestic violence and have unequivocally contributed to the development of the case-law of the Court (McQuigg 2011, 50). The findings of the Court in the case Kontrová v. Slovakia were subsequently confirmed two years later in its judgment delivered in the case Branko Tomašić and Others v. Croatia (no. 46598/06, 15 January 2009). 
The concept of positive obligations was further applied and articulated in the case Bevacqua and S. v. Bulgaria (no. 71127/01, 12 June 2008). The applicant in this case was a victim of domestic violence. The case represents a landmark case since the Court held for the first time that there was a violation of the Convention concerning the actual abuse suffered by the applicant herself, as a victim of domestic violence. However, the case Bevacqua and S. $v$. Bulgaria was criticized because of the absence of focus on the discrimination aspect (Hasselbacher 2010, 208-209).

The discrimination aspect of violence against women was addressed by the Court in the case Opuz v. Turkey (no. 33401/02, ECHR 2009). Namely, this case is considered a landmark case because for the first time in a domestic violence case the Court held that there had been a violation of Article 14 of the Convention (prohibition of discrimination, in conjunction with Article 2 and Article 3. Namely, the Court recognized that domestic violence affected mainly women, while the general and discriminatory judicial passivity in Turkey created a climate that was conducive to it. According to the Court's findings, the violence suffered by the applicant and her mother could therefore be regarded as having been gender-based and discriminatory against women. Despite the reforms carried out by the Turkish Government in recent years, the overall unresponsiveness of the judicial system and the impunity enjoyed by aggressors, as found in the applicant's case, indicated an insufficient commitment on the part of the authorities to take appropriate action to address domestic violence (Opuz v. Turkey, no. 33401/02, § 200, ECHR 2009).

It is important to emphasize that the Court's judgments in the cases Bevacqua and $S$. v. Bulgaria and Opuz v. Turkey "recognize and advance the due diligence standard in the context of domestic violence" (Hasselbacher 2010, 203). Namely, there are several minimums foreseen that provide practical substance in order to assess the adherence of the state "to the principles of protection, investigation, and prosecution" (Hasselbacher 2010, 203).

These minimums incorporate the availability of a judicial mechanism in order to obtain protection measures, as well as prosecution for all crimes of domestic violence in the public interest. As it was pointed out, the Court went a step further in the case Opuz v. Turkey and recognized that the failure of the national authorities to exercise due diligence represents a gender-based discrimination.

In the case Valiuliene v. Lithuania (no. 33234/07, 26 March 2013), concerning the complaint by a woman who was a victim of domestic violence about the state's failure to investigate her allegations of ill-treatment and to bring her partner to account, the adequateness of the 'Osman test' in situations of domestic violence was criticized by Judge de Albuquerque. Namely, in the Concurring opinion he emphasized that the stage of an 'immediate risk' was often too late for the national authorities to intervene. Namely, "the recurrence and escalation inherent in most cases of domestic violence makes it somehow artificial, even deleterious, to require an immediacy of the risk" (Valiuliené v. Lithuania 2013). In that sense, "a more rigorous standard of diligence is especially necessary in the context of certain societies" (Valiuliené v. Lithuania 2013). He concludes that "the emerging due 
diligence standard in domestic violence cases is stricter than the classical Osman test" (Valiuliené v. Lithuania 2013).

In the case Talipis $v$. Italy (no. 41237/14, 2 March 2017), concerning the conjugal violence suffered by the applicant, which resulted in the murder of her son and her own attempted murder, "the Court seems to follow the way paved by Judge de Albuquerque" (De Vido 2017, 5). According to the Court, "the risk of a real and immediate threat (...) must be assessed taking due account of the particular context of domestic violence". Furthermore, "In such a situation it is not only a question of an obligation to afford general protection to society (...) but above all to take account of the recurrence of successive episodes of violence within the family unit" (Talpis v. Italy, no. 41237/14, § 122, 2 March 2017).

Similarly, in the case O'Keeffe v. Ireland (no. 35810/09, § 146, ECHR 2014), concerning the responsibility of the national authorities for the sexual abuse of a nine year old schoolgirl by a lay teacher in an Irish National School, the Court emphasized the importance of the context in which the human violation occurred (De Vido 2017, 5). In the Court's view, "having regard to the fundamental nature of the rights guaranteed by Article 3 and the particularly vulnerable nature of children, it is an inherent obligation of government to ensure their protection from ill-treatment, especially in a primary-education context, through the adoption, as necessary, of special measures and safeguards" (O'Keeffe $v$. Ireland [GC], no. 35810/09, § 146, ECHR 2014).

However, in the judgment delivered in the case Kurt v. Austria (no. 62903/15, 4 July 2019) two years later, concerning the murder of the applicant's son by his father after previous allegations of domestic violence by the applicant against the father, the Court followed the classical 'Osman test'. Five days after the judgment in the case Kurt v. Austria, the Court issued a judgment in the case Volodina v. Russia (no. 41261/17, 9 July 2019), concerning the applicant's complaint that the national authorities had failed to protect her from repeated domestic violence, including assaults, kidnapping, stalking and treats. The applicant also alleged that the current Russian legal system is not adequate in order to deal with such violence and discriminatory against women. In this case, the Court applied the approach established in the case Talpis $v$. Italy regarding the obligation of the national authorities under Article 3 of the Convention. The issues that are raised in rape and sexual abuse cases are to a large extent comparable to those that are raised in domestic violence cases. Namely, those are the issues of the existence and scope of the states' positive obligations, the article under which the Court should examine the violation alleged in the complaint, as well as the necessary means in order to achieve effective protection of the victims.

The first rape case raised before the ECtHR is the case $X$ and $Y v$. the Netherlands (26 March 1985, Series A no. 91). The case concerned the responsibility of the state for the rape of a girl with a mental handicap (the second applicant), in the home for children with mental disabilities where she lived, the day after her sixteenth birthday (which was the age of consent for sexual intercourse in the Netherlands) by a relative of the person in charge. The girl 
deemed unfit to sign an official complaint due to her low mental age, so her father (the first applicant) signed in her place. However, the proceedings were initiated against the perpetrator as the girl had to file the complaint itself. The Court recalled that in addition to the primary negative undertaking of the State in the context of Article 8 of the Convention, there may also be positive obligations inherent in an effective respect for private or family life.

Accordingly, the Court found that the protection afforded by civil law in respect of the second applicant was insufficient as fundamental values and essential aspects of private life were concerned in the case. Therefore, effective deterrence was necessary in this area, which could be achieved only by criminal law provisions. Taking in consideration the failure of the Dutch Criminal Code to provide her with practical and effective protection, as well as the nature of the wrongdoing, the Court found that the second applicant had been the victim of a violation of Article 8. The judgment delivered in the case $X$ and $Y v$. the Netherlands is considered a landmark judgment as it developed the concept of positive obligations regarding rape cases.

The cases C.R v. the United Kingdom (22 November 1995, Series A no. 335-C) and S.W. v. the United Kingdom (22 November 1995, Series A no. 335-B) put an end of the "marital rape exemption". These cases are also specific because they were brought before the ECtHR by the men who were convicted of rape and attempted rape.

Another important case that concerns rape is Aydin v. Turkey 25 September 1997, Reports of Judgments and Decisions 1997-VI). In this case, the Court considered rape as a form of torture under Article 3 of the Convention for the first time. The case concerned a complaint by a young Turkish woman of Kurdish origin (17 years old at the relevant time), who was arrested without explanation and taken into custody, along with two other members of her family. She was blindfolded, beaten, stripped naked, sprayed with cold water from high-pressure jets while being spun in a tire before being raped by a member of the security forces, and then again beaten for about an hour by several people. A subsequent medical examination by a doctor, who had never before dealt with a rape case, found her hymen torn and widespread bruising on her thighs. The Court emphasized that rape of a detainee by a state official must be considered to be an especially grave and abhorrent form of illtreatment given the ease with which the offender can exploit the vulnerability and weakened resistance of his victim. Furthermore, it stressed that rape leaves deep psychological scars on the victim. The Court found that both the accumulation of acts of physical and mental violence inflicted on the applicant while in custody and the especially cruel act of rape to which she had been subjected had amounted to torture, in violation of Article 3 of the Convention. In addition, an allegation of rape by an official in custody required that the victim be examined with all appropriate sensitivity by independent doctors with the relevant expertise. That did not occur, making the investigation deficient and denying the applicant access to compensation, in violation of Article 13 of the Convention.

The case M.C. v. Bulgaria (no. 39272/98, ECHR 2003-XII) confirmed that rape can also be considered under Article 3 in situations that only involve non-state actors. It confirmed as 
well the content of the positive obligations of the state in terms of effective implementation of measures of protection, and provided the definition of rape. Namely, one of the most significant findings of the Court in this case is the emphasis on consent rather than force regarding the definition of rape. The judgment delivered in the case M.C. v. Bulgaria is considered a landmark judgment as the national authorities are now obliged to prosecute all forms of rape, regardless of the fact whether the victim has actively resisted. The Court used a gender-sensitive approach in this case, in order to achieve such an improvement (Radacic $2008,130)$. However, there are also some critics addressed to the case, as regards the lack of articulation of the issues in question as inequality issues. Namely, in the acquaintance-rape case of M.C. v. Bulgaria, the inadequacies of Bulgarian law in dealing with cases of rape were treated only as a violation of the substantive law (Londono 2009, 657-667).

Furthermore, in cases such as M.G.C. v. Romania(no. 61495/11, 15 March 2016) and I.C. v. Romania (no. 36934/08, 24 May 2016), the Court established that States have a positive obligation to adopt and apply criminal law provisions that effectively punish rape, and that they must especially provide protection for children and other vulnerable persons.

In the case E.B. v. Romania (no. 49089/2010, 19 March 2019), the Court applied the existing case-law as regards the criminalization of rape and sexual violence, as well as the context-sensitivity that is required regarding vulnerable applicants. The obligation based in the ECHR to criminalize may sound strange.

Namely, these types of cases expand the State's coercive power, while most of the case-law of the Court, for example under Articles 5, 6 and 7 of the ECHR, is focused on constraining the State's coercive power and the domestic criminal law. The obligation for the State to criminalize constitutes a part of States' so-called "coercive obligations" (Heri 2009).

\section{ISTANBUL CONVENTION AS A MEANS FOR INTERPRETATION OF THE EUROPEAN CONVENTION ON HUMAN RIGHTS}

The Istanbul Convention is "the most far reaching international treaty to tackle violence against women" (Organization of American States and Council of Europe 2014, 89). It is particularly important due to the fact that "it breaks new ground by requesting states to criminalize the various forms of violence against women, including physical, sexual and psychological violence, stalking, sexual harassment, female genital mutilation, forced marriage, forced abortion and forced sterilization" (Organization of American States and Council of Europe 2014, 89).

The principles and standards developed in the case-law of the ECtHR as regards cases of VAW are now incorporated in the Istanbul Convention and thus became legally binding (Duban and Radacic 2017, 40). In that sense, the Istanbul Convention incorporates the 'due diligence' standard and defines it as the States' obligation to "prevent, investigate, punish and provide reparation for acts of violence perpetrated by non-state actors" (Council of Europe 
2011, Article 5). The argumentative moves of the ECtHR in certain cases concerning VAW seems to show that the provisions of the Istanbul Convention "can constitute 'relevant rules of international law' under Article 31(3)(c) of the Vienna Convention on the Law of the Treaties (...) in the interpretation of applicable articles of the European Convention on Human Rights" (De Vido 2017, 1).

For example, the judgment delivered by the Court in the case Talpis V. Italy demonstrates that the provisions of the Istanbul Convention are used as relevant rules of international law in the interpretation of the ECHR, in order to identify the obligations of the national authorities in preventing domestic violence (Talpis v. Italy, no. 41237/14, § 58, 2 March 2017).

In this sense, when looking into the alleged violation of Article 3, the Court stresses that "special diligence is required in dealing with domestic violence cases" and recognizes that "the specific nature of domestic violence as recognized in the Preamble to the Istanbul Convention (...) must be taken into account in the context of domestic proceedings" (Talpis $\mathrm{V}$. Italy, no. 41237/14, § 129, 2 March 2017). Furthermore, the Court emphasized that "the Istanbul Convention imposes a duty on the States Parties to take 'the necessary legislative or other measures to ensure that investigations and judicial proceedings in relation to all forms of violence covered by the scope of this Convention are carried out without undue delay while taking into consideration the rights of the victim during all stages of the criminal proceedings" (Talpis v. Italy, no. 41237/14, § 129, 2 March 2017). 


\section{CONCLUSION}

Given that it has been widely acknowledged that most GBV is inflicted on women and girls, by men, the term gender-based violence and the term violence against women are often used interchangeably, including in some international conventions. As there is an increasing tendency to use GBV as a broader term compared to VAW, it seems that the two terms are not synonymous. However, it should not be forgotten that using the "gender based" aspect is very important as it emphasizes the fact that most forms of violence against women have its roots in the inequality of power between women and men.

The ECtHR has built up a substantial body of jurisprudence regarding almost all forms of GBV. Namely, despite the lack of specific provisions in the ECHR concerning GBV, the Court has developed an extensive case-law in this filed, by using a number of provisions in the Convention as relevant to GBV. In this sense, the Court repeatedly applied the Articles 2 , $3,4,6,8,13$ and 14 in the examination of GBV cases. The Court dealt mostly with cases related to domestic violence, and rape and sexual abuse, but it also addressed other forms of GBV, such as ill-treatment in detention, police violence, female genital mutilation, honor crime, forced marriage, risk of trafficking and re-trafficking, social exclusion, trafficking in human beings, etc.

There have been very positive developments within the case-law of the Court concerning different forms of GBV, such as entailing both negative and positive obligations for the State in the context of Articles 2, 3, 4 and 8; requiring from States to also act in situations occurring solely in the private sphere; determining that GBV amounts to discrimination; establishing the principle that in certain circumstances domestic violence and rape may fall under Article 3, etc.

It seems that, in general, the approach of the Court followed a similar path when examining the different forms of GBV. However, there are a few cases, such as the case Kurt v. Austria (no. 62903/15, 4 July 2019), where it seems that the Court departed from its previously established case-law and did not take into account certain standards regarding domestic violence. Namely, this approach carries a potential to undermine the progress made within the case-law of the Court concerning domestic violence cases and create uncertainty as regards the standards that should be followed in such cases. At the same time, it is also noteworthy that at the moment of writing this paper, the judgment delivered in this case is still not final in terms of Article 44(2) of the Convention. Namely, it remains to be seen whether the Court will clarify this issue in its future case-law.

It is evident from the analysis conducted in respect of the case-law of the ECtHR that the spate of cases on GBV considered by the Court is remarkable, and provides solid protection from different forms of GBV. However, as it seems that certain aspects of the caselaw of the Court on GBV are somewhat inconsistent, it is very important for the Court to fully clarify its approach in this sense, particularly given that its judgments are the main guidelines for the States in fulfilling properly their obligations arising from the Convention. 
Another significant development as regards the protection from GBV before the ECtHR is the entry into force of the Istanbul Convention. Namely, as seen from the analyses conducted, it seems that the provisions of the Istanbul Convention, as relevant rules of international law, are useful in order to expand the scope of application of the Convention provisions that are relevant in cases concerning GBV. 


\section{REFERENCES}

1. De Vido, Sara. 2017. "States' Positive Obligations to Eradicate Domestic Violence: The Politics of Relevance in the Interpretation of the European Convention on Human Rights." ESIL Reflections 6 (6): 1-11

2. Duban, Elisabeth and Radacic, Ivana. 2017. Training Manual for Judges and Prosecutors on Ensuring Women's Access to Justice. Strasbourg: Partnership for Good Governance

3. European Court of Human Rights. 2020. "Factsheet on Violence against Women." Accessed 23 July 2020. https://www.echr.coe.int/Documents/FS Violence Woman ENG.pdf

4. Hasselbacher, Lee, "State Obligations Regarding Domestic Violence: the European Court of Human Rights, Due Diligence, and International Legal Minimums of Protection."Northwestern Journal of International Human Rights 8 (2): 190-215

5. Heri, Corina. 2019. "Vulnerability, Rape, and Coercive Obligations: A Discussion of E.B. v. Romania." Strasbourg Observers, 23 July 2020 https://strasbourgobservers.com/2019/04/12/vulnerability-rape-and-coerciveobligations-a-discussion-of-e-b-v-romania/\#more-4337

6. Londono, Patricia. 2009. "Developing Human Rights Principles in Cases of GenderBased Violence: Opuz v. Turkey in the European Court of Human Rights." Human Rights Law Review 9 (4): 657-667 https://doi.org/10.1093/hrlr/ngp022

7. McQuigg, Ronagh J.A. 2011. International Human Rights Law and Domestic Violence, The effectiveness of international human rights law. Oxford: Routledge

8. Organization of American States and Council of Europe. 2014. Regional Tools to Fight Violence Against Women: The Belem do Para and Istanbul Conventions. WashingtonStrasbourg: Organization of American States and Council of Europe https://www.oas.org/en/mesecvi/docs/MESECVI-CoE-CSWPub-EN.pdf

9. Radacic, Ivana. 2008. "Rape Cases in the Jurisprudence of the European Court of Human Rights: Defining Rape and Determining the Scope of the State's Positive Obligations." European Human Rights Law Review 13 (3): 120-135

10. UN High Commissioner for Refugees. 2003. Sexual and Gender-Based Violence for Refugees, Returnees and Internally Displaced Persons, Guidelines for Prevention and Response. UN High Commissioner for Refugees https://www.unhcr.org/protection/women/3f696bcc4/sexual-gender-based-violenceagainst-refugees-returnees-internally-displaced.html

11. UN Women. 2013. "Facts and Figures: Ending Violence against Women."Accessed 23 July 2020. https://www.unwomen.org/en/what-we-do/ending-violence-againstwomen/facts-and-figures 
12. UN Human Rights Office of the High Commissioner. 2011. Monitoring and Protecting the Human Rights of Women. UN Human Rights Office of the High Commissioner https://www.ohchr.org/Documents/Publications/Chapter28 MonitoringAndProtecting. $\underline{\mathrm{pdf}}$

13. UN Human Rights Office of the High Commissioner. 2014. Sexual and Gender-Based Violence in the Context of Transitional Justice. UN Human Rights Office of the High Commissioner https://www.ohchr.org/Documents/Issues/Women/WRGS/OnePagers/Sexual and gen der-based violence.pdf

14. World Health Organization. 2013. Global and Regional Estimates on Violence Against Women: Prevalence and Health Effects of Intimate Partner Violence and Non-Partner Sexual Violence. World Health Organization https://apps.who.int/iris/bitstream/handle/10665/85239/9789241564625 eng.pdf;jsessi onid=236BF88F1BA19FCC1087BE455E141483? sequence $=1$

15. World Health Organization. 2017. "Violence Against Women." Accessed 23 July 2020. https:/www.who.int/en/news-room/fact-sheets/detail/violence-against-women 


\section{Legal documents}

1. African Union, Protocol to the African Charter on Human Rights and People's Rights on the Rights of Women in Africa, 11 July 2003

2. Council of Europe, Convention for the Protection of Human Rights and Fundamental Freedoms as amended by Protocols No.11 and No.14, 4 November 1950, European Treaty Series - No.5

3. Council of Europe, Convention on Preventing and Combating Violence against Women and Domestic Violence, 11 May 2011, Council of Europe Treaty Series - No.210

4. Council of Europe, Explanatory Report to the Council of Europe Convention on Preventing and Combating Violence against Women and Domestic Violence, 11 May 2011a, Council of Europe Treaty Series - No.210

5. Organization of American States (OAS), Inter-American convention on the Prevention, Punishment and Eradication of Violence against Women ("Convention of Belém do Pará), 9 June 1994

6. UN Committee on the Elimination of Discrimination against Women (CEDAW), CEDAW General Recommendation No. 19: Violence against women, 1992

7. UN General Assembly, Declaration on the Elimination of Violence against Women, 20 December 1993, A/RES/48/104 


\section{Cases of the European Court of Human Rights}

1. Aiery v. Ireland, 9 October 1979, Series A no.39

2. Aydın v. Turkey, 25 September 1997, Reports of Judgments and Decisions 1997-VI

3. Bevacqua and S. v. Bulgaria, no. 71127/01, 12 June 2008

4. BrankoTomašić and Others v. Croatia, no. 46598/06, 15 January 2009

5. C.R. v. the United Kingdom, 22 November 1995, Series A no. 335-C

6. E.B. v. Romania, no. 49089/2010, 19 March 2019

7. I.C. v. Romania, no. 36934/08, 24 May 2016

8. Kontrová v. Slovakia, no. 7510/04, 31 May 2007

9. Kurt v. Austria, no. 62903/15, 4 July 2019

10. M.C. v. Bulgaria, no. 39272/98, ECHR 2003-XII

11. M.G.C. v. Romania, no. 61495/11, 15 March 2016

12. O'Keeffe v. Ireland [GC], no. 35810/09, ECHR 2014 (extracts)

13. Opuz v. Turkey, no. 33401/02, ECHR 2009

14. Osman v. the United Kingdom, 28 October 1998, Reports of Judgments and Decisions 1998-VIII

15. S.W. v. the United Kingdom, 22 November 1995, Series A no. 335-B

16. Talpis v. Italy, no. 41237/14, 2 March 2017

17. Valiulienè v. Lithuania, no. 33234/07, 26 March 2013

18. Volodina v. Russia, no. 41261/17, 9 July 2019

19. $X$ and $Y$ v. the Netherlands, 26 March 1985, Series A no. 91 